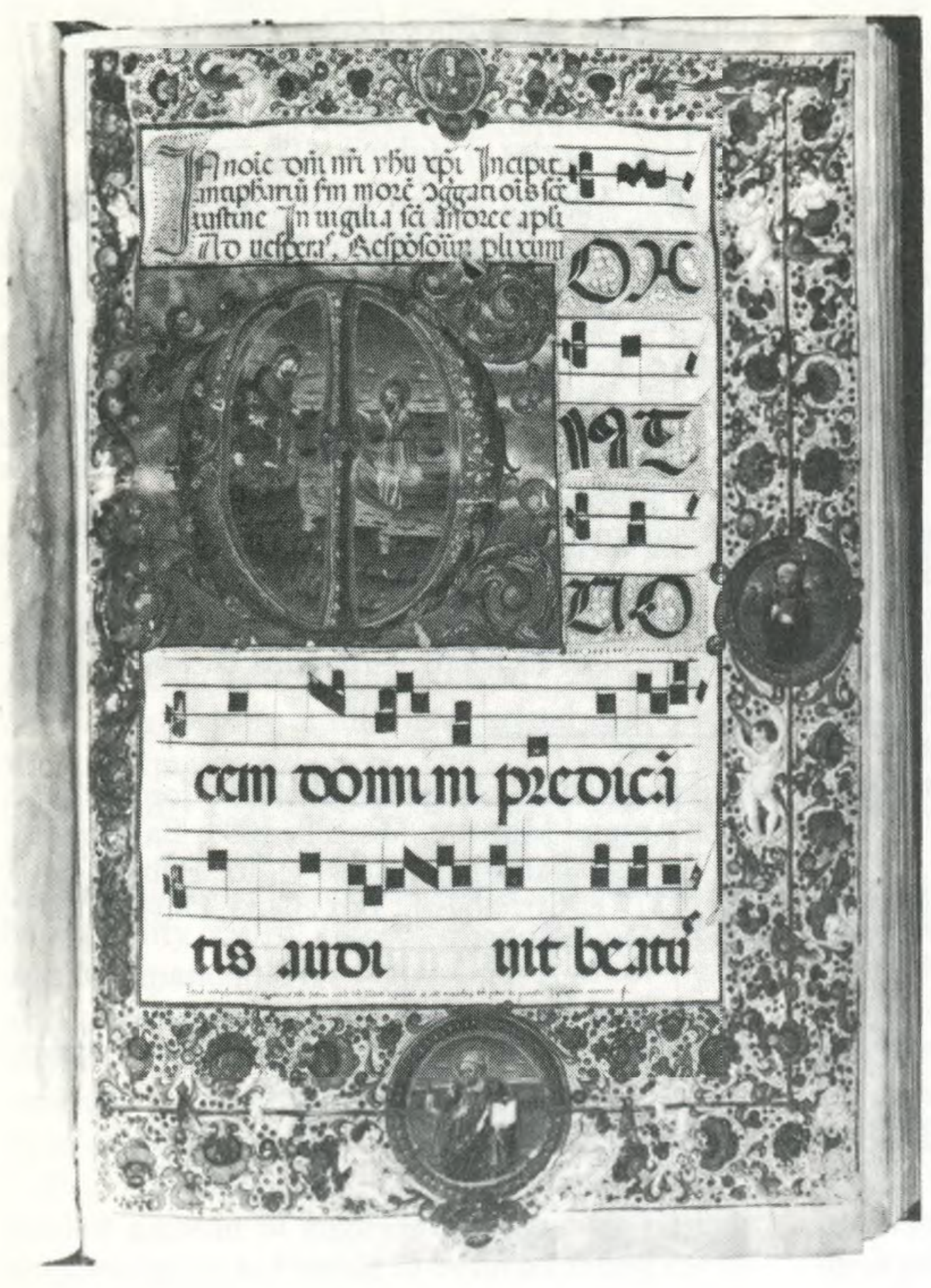

This Latin manuscript, a 15th century antiphonal used in the performance of church services, went on view for the first time in December in an exhibition at Columbia University that marked the opening of its new Rare Book and Manuscript Library. The display of 121 treasures from the collection is installed in the gallery of the new library, pictured on the cover.

\title{
Rare book library opens at Columbia
}

Columbia University's new Rare Book and Manuscript Library, built at a cost of $\$ 3$ million atop Butler Library, was unveiled to the public on December 6 with the opening of an inaugural exhibition of important holdings ranging from the Babylonians to the Beats.

An illustrated history of the library and its collections, entitled The Rare Book and Manuscript Library of Columbia University: Collections and Treasures, has been published to celebrate the opening. Although begun in 1761 with the founding of the University, the Rare Book and Manuscript Library was formally organized as a separate unit of the libraries in 1930. It now houses some 500,000 rare books, 22 million manuscripts, and thousands of art works and realia.

The 121 treasures described in detail in the commemorative book are on view through February 1985 in the inaugural exhibition, "Treasures from the Collections." Included are such ancient items as a 4,000-year-old Mesopotamian cylinder seal on public view for the first time; modern manuscripts including the 1956 hand-corrected typescript of poet and alumnus Allen Ginsberg's "Howl; a daguerrotype portrait of Edgar Allan Poe taken three weeks before his death; autograph manuscript dia- ries of George Washington for 1795 and 1798; and a 1458 Canon missae printed in Mainz.

Pat Battin, Columbia vice-president and university librarian, wrote the foreward to the book and Kenneth A. Lohf, rare book and manuscript librarian, provided a detailed account of the growth and scope of the library's holdings. The section describing the treasures was edited by Rudolph Ellenbogen, assistant librarian for rare books.

The exhibition marks the first time the Rare Book and Manuscript Library has had the facilities to host a major showing. Previously without exhibition space and located in various parts of Butler Library, the library has now been unified in a structure especially designed for the display, preservation, and scholarly use of its holdings.

The new climate-controlled two-story structure, designed by the New York architectural firm of Cain, Farrell and Bell, is built on the sixth floor setback on Butler's south side. Extensive interior use of glass walls and partitions and a skylight running the entire length of the 230-foot library give a sense of openness to a structure deliberately windowless except for two high circular windows on the east and west end walls. 